\title{
Reactive oxygen species regulate the generation of urokinase plasminogen activator in human hepatoma cells via MAPK pathways after treatment with hepatocyte growth factor
}

\author{
Kyung Hee Lee ${ }^{1}$ and Jae-Ryong Kim ${ }^{2,3,4}$ \\ 'Department of Hemato-Oncology \\ ${ }^{2}$ Department of Biochemistry and Molecular Biology \\ ${ }^{3}$ Aging-associated Vascular Disease Research Center \\ College of Medicine, Yeungnam University \\ Daegu 705-717, Korea \\ ${ }^{4}$ Corresponding author: Tel, 82-53-620-4342; \\ Fax, 82-53-654-6651; E-mail, kimjr@med.yu.ac.kr \\ DOI 10.3858/emm.2009.41.3.021
}

Accepted 18 November 2008

Abbreviations: HGF, hepatocyte growth factor; ROS, reactive oxygen species; uPA, urokinase plasminogen activator

\begin{abstract}
Tumor cells are known to produce larger amounts of reactive oxygen species (ROS) than normal cells. Although numerous reports have indicated the importance of ROS in urokinase plasminogen activator (UPA) production, the precise mechanisms remain controversial. In our study, we investigated the effect of ROS on uPA generation in human hepatoma cells, HepG2 and Hep 3B. We determined the effects of hepatocyte growth factor (HGF) on the regulation of ROS, which resulted in suppression of ROS production, as measured with the fluorescent probe, 2'-7'-dichlorofluorescein diacetate. The role of HGF in modulating ROS production, particularly that regulated by Rac-1, was determined. HGF suppressed the increment in Rac-1-regulated ROS in both cell lines. Treatment with $200 \mu \mathrm{M}$ of $\mathrm{H}_{2} \mathrm{O}_{2}$ showed a 1.6-2.1 fold increment in HGF, but a little increment occurred at $500 \mu \mathrm{M}$ of $\mathrm{H}_{2} \mathrm{O}_{2}$. It looks no dose dependent manner. Combined treatment with $\mathrm{H}_{2} \mathrm{O}_{2}$ and $\mathrm{HGF}$, resulted in a slightly increased production of HGF compared to no treatment (control). Also, $\mathrm{H}_{2} \mathrm{O}_{2}$ upregulated uPA expression in both hepatoma cell lines. To identify the downstream pathways regulated by ROS, we treated cells with PD 98059, an MEK inhibitor, and SB 203580, a p38 inhibitor, after treatment with $\mathrm{H}_{2} \mathrm{O}_{2}$, and showed negative control between ERK and p38 kinase activities for UPA regulation. We found that HGF modulate Rac-1-regulated
\end{abstract}

ROS production through activation of Akt and ROS regulates uPA production via MAP kinase, which provides a novel clue to clarify the mechanism underlying hepatoma progression.

Keywords: hepatocyte growth factor; metastasis; mitogen-activated protein kinases; neoplasm metastasis; reactive oxygen species; urokinase-type plasminogen activator

\section{Introduction}

Reactive oxygen species (ROS), including super oxidase $\left(\mathrm{O}^{2-}\right)$, hydroxyl radical $(-\mathrm{OH})$, and $\mathrm{H}_{2} \mathrm{O}_{2}$, are constantly generated in aerobic organisms during intracellular metabolism and in response to environmental stimuli. Considerable evidence indicates that ROS play a central role in the key intracellular signal transduction pathway for a variety of cellular process (Aslan and Ozben, 2003; Poli et al., 2004; Chiarugi, 2005). Recently, ROS were proposed to be involved in tumor metastasis, which is a complicated process, including the epithelialmesenchymal transition (EMT), migration, invasion of the tumor cells, and angiogenesis around the tumor lesion (Radisky et al., 2005; Storz, 2005).

Hepatocyte growth factor (HGF), which is identical to scatter factor, is known to represent a multipotent growth factor predominantly secreted by mesenchymal cells (Maulik et al., 2002). HGF acts via its receptor, c-Met. Numerous tumor cells express HGF, c-Met, or both, and the HGF/c-Met axis is thought to be highly involved in tumor cell invasion and metastasis (Parr and Jiang, 2001; Lee et al., 2003). Miura et al. (2003) reported that ROS induce the expression of HGF genes and stimulate the autocrine action of HGF in invading ascites hepatoma cells. HCC is associated with a high rate of intrahepatic invasion, which requires the degradation of the extracellular matrix by proteolytic enzymes including serine proteinases such as urokinase plasmingen activator (UPA). Several studies have reported overexpression of UPA in malignant tumors, including cancer of the breast, colon, lung, and skin, and have found these overexpressions to be associated with poor prognoses (Andreasen et al., 1997). 


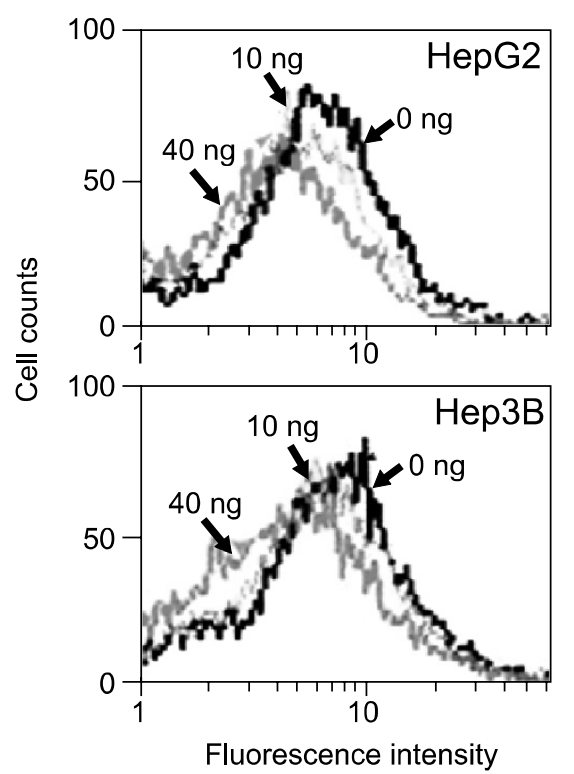

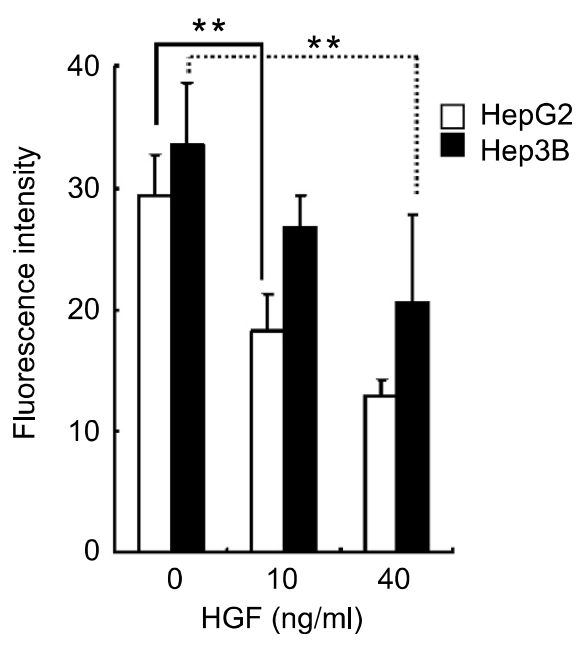

Figure 1. Effect of HGF on ROS accumulation. Serum-starved cells were treated with increasing concentrations of $\operatorname{HGF}(0,10$ and 40 $\mathrm{ng} / \mathrm{ml})$. After incubation for $1 \mathrm{~h}$, cells were incubated with DCF-DA (10 $\mu M)$ for $10 \mathrm{~min}$. The cells were washed with PBS, trypsinized, and resuspended in PBS. The intensity of DCF-fluorescence was immediately measured with a flow cytometer. Representative data from 3 independent experiments were shown. Values are means $\pm S D$ of three independent experiments. Statistical significance was estimated by Student's $t$-test $\left.{ }^{* *} P<0.01\right)$.
One of the important downstream signal cascades involved in tumor invasion is MAPK, including ERK, p38, and JNK (Berra et al., 1995; Schonwasser et al., 1998). MAPK has been established to be a major signal cascade for EMT and cell migration in diverse systems. Gupta et al. (1999) reported that increased ROS levels enhance MAPK activity for malignant progression of a mouse keratinocyte cell line.

However, despite the positive correlation between the increased generation of ROS and the invasion of cancer, the specific mechanisms by which antioxidants act to suppress cancer development through ROS is unknown. In this study, the modulation of ROS with c-Met activation by HGF was determined. Finally, we have reported a negative relationship between ERK with p38 kinase in the regulation of UPA production.

\section{Results}

\section{HGF suppresses ROS generation in c-Met overexpressing hepatoma cells}

The intracellular ROS levels in c-Met overexpressing HepG2 and Hep3B cells treated with HGF were determined using DCF-DA by flow cytometry. Stimulation of c-Met overexpressing hepatoma cells with HGF significantly reduced the basal level of ROS in a dose-dependent manner (Figure 1).

\section{A}

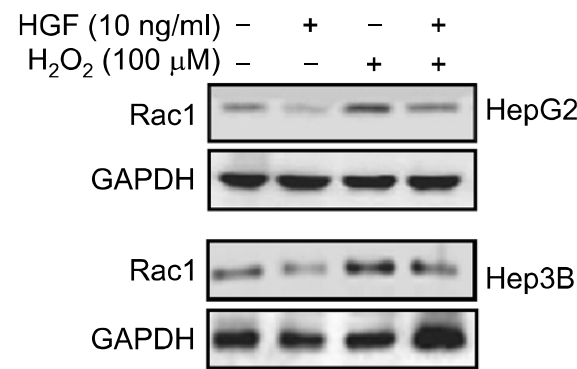

B

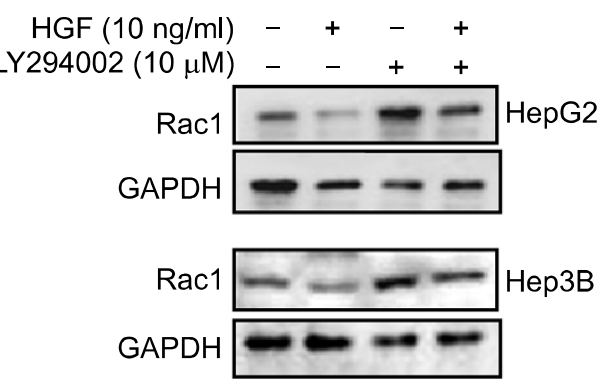

Figure 2. Effects of $\mathrm{HGF}$ and $\mathrm{H}_{2} \mathrm{O}_{2} / \mathrm{LY} 294002$ on Rac-1 activation. Serum-starved cells was pretreated with or without $\mathrm{H}_{2} \mathrm{O}_{2}(100 \mu \mathrm{M})$ for $30 \mathrm{~min}$ and then treated with or without $10 \mathrm{ng} / \mathrm{ml} \mathrm{HGF}(\mathrm{A})$. Serum-starved cells were pretreated with or without $L Y(10 \mu \mathrm{M})$ for 30 min and then treated with or without HGF $(B)$. After incubation for 15 min, cells were collected, washed, and then sonicated. Cell lysates were immunoprecipitated with PAK-1 PBD and Rac1 activation was measured by Western blotting with a Racl antibody. Representative data from 3 independent experiments were shown. 


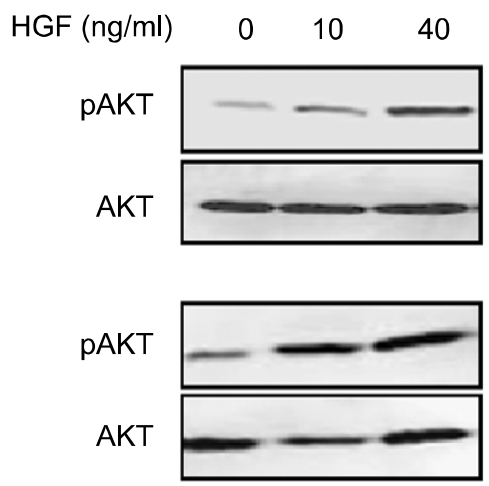

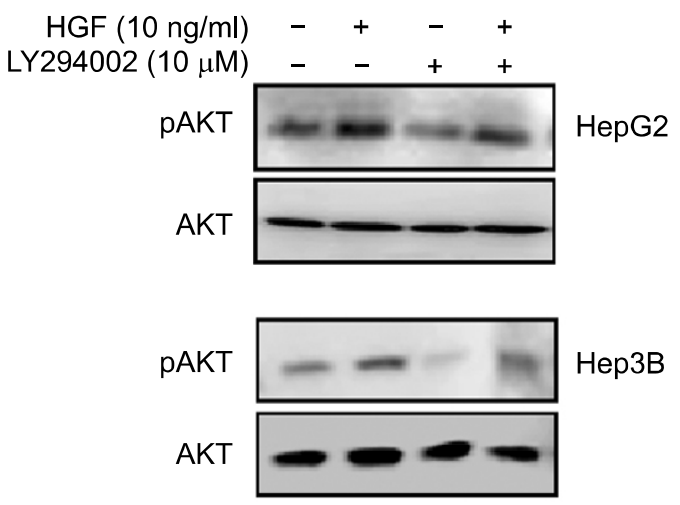

Figure 3. Effect of HGF or LY 294002 on Akt phosphorylation. Serum-starved cells were treated with increasing concentrations of HGF for $15 \mathrm{~min}$. The protein levels of Akt and phospho-Akt were measured by Western blot analysis (A). Serum-starved cells were pretreated with LY 294002 $(10 \mu \mathrm{M})$ for $30 \mathrm{~min}$ and then treated with HGF $(10 \mathrm{ng} / \mathrm{ml})$. After incubation for $15 \mathrm{~min}$, the protein levels of Akt and phospho-Akt were determined by Western blot analysis (B). Representative data from 3 independent experiments were shown.

\section{HGF suppresses Rac-1-regulated ROS production through activation of Akt}

We examined the role of HGF in modulating ROS production, particularly which is regulated by Rac-1. Treatment with HGF suppressed a basal activity of Rac- 1 as well as an increase in Rac-1 activity induced by $\mathrm{H}_{2} \mathrm{O}_{2}$ treatment (Figure 2A). Pretreatment of cells with LY 294002, a PI3-kinase inhibitor, activated Rac-1 (Figure 2B). Next, we examined whether Akt is involved in the reduction of ROS level induced by HGF. Treatment of HepG2 and Hep3B cells with HGF caused Akt activation in a dose-dependent manner and pre-incubation of cells with LY 294002 reduced HGF-induced Akt phosphorylation (Figure 3). Furthermore, inhibition of Akt by LY 294002 treatment increased ROS levels (Figure 4). More importantly, the effect of LY 294002 was abolished by HGF, as determined using DCF-DA by flow cytometry (Figure 4). These results suggest that $\mathrm{Pl}$-kinase is an essential mediator through which HGF inhibits the ROS generation.

\section{Up-regulation of HGF mRNA levels in hepatoma cell lines treated with $\mathrm{H}_{2} \mathrm{O}_{2}$}

To understand the mechanism of uPA production of ROS, we examined HGF gene expression using the RT-PCR method. The levels of HGF mRNA were 1.6-2.1 fold higher in cells treated with 100 $\mu \mathrm{M} \mathrm{H} \mathrm{H}_{2}$ than in untreated cells. However, HGF mRNA levels were decreased when treated with

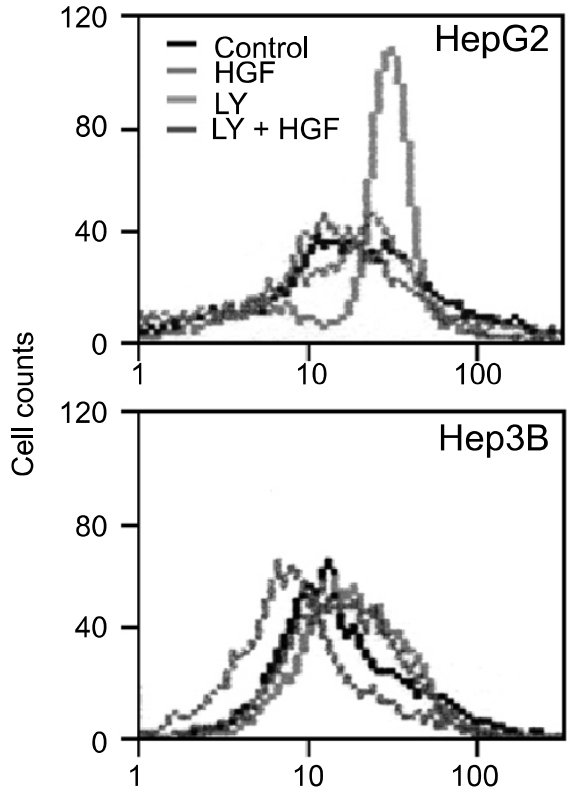

Fluorescence intensity

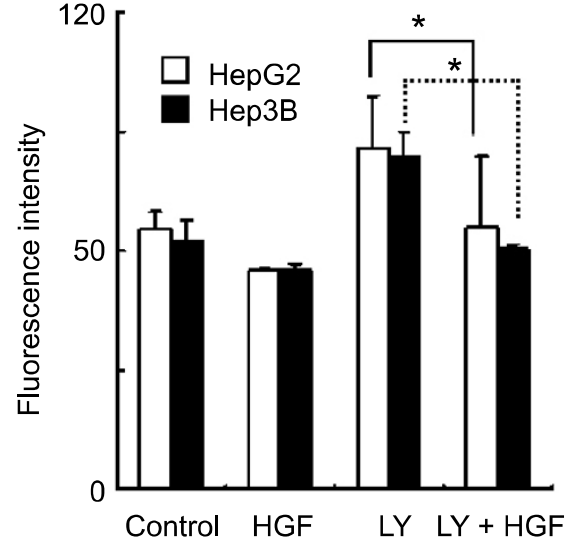

Figure 4. Effect of LY 294002 on ROS accumulation. Serum-starved cells were pretreated with LY 294002 $(10 \mu \mathrm{M})$ for $30 \mathrm{~min}$ and then treated with HGF $(10 \mathrm{ng} / \mathrm{ml})$. The intensity of DCF fluorescence was measured with flow cytometry. Representative data from 3 independent experiments were shown. Values are means \pm SD of three independent experiments. Statistical significance was estimated by Student's $t$-test $\left({ }^{*} P<\right.$ 0.05). 
$500 \mu \mathrm{M} \mathrm{H}_{2} \mathrm{O}_{2}$ (Figure 5). This might be due to $\mathrm{H}_{2} \mathrm{O}_{2}$ cytotoxicity. Subsequently, we measured $\mathrm{HGF}$ mRNA levels from both cell lines in the absence or presence of exogenous $\mathrm{HGF}$ and/or $\mathrm{H}_{2} \mathrm{O}_{2}$. The

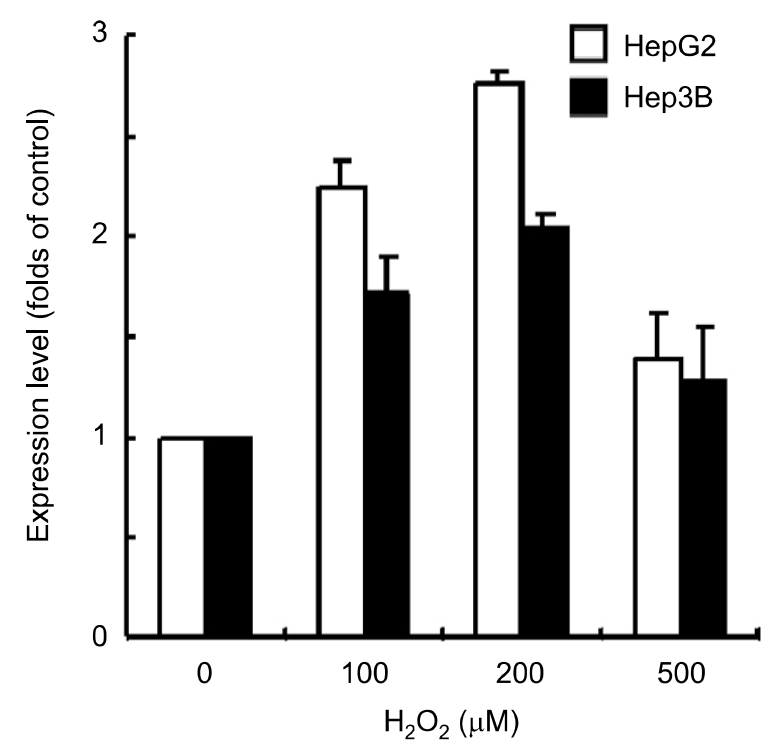

Figure 5. Effect of $\mathrm{H}_{2} \mathrm{O}_{2}$ on the levels of HGF mRNA. Cells were serum-starved and treated with increasing concentrations of $\mathrm{H}_{2} \mathrm{O}_{2}(0,100$, 200 , and $500 \mu \mathrm{M})$. The expression level of HGF was measured by real-time RT-PCR. Values are means \pm SD of three independent experiments.

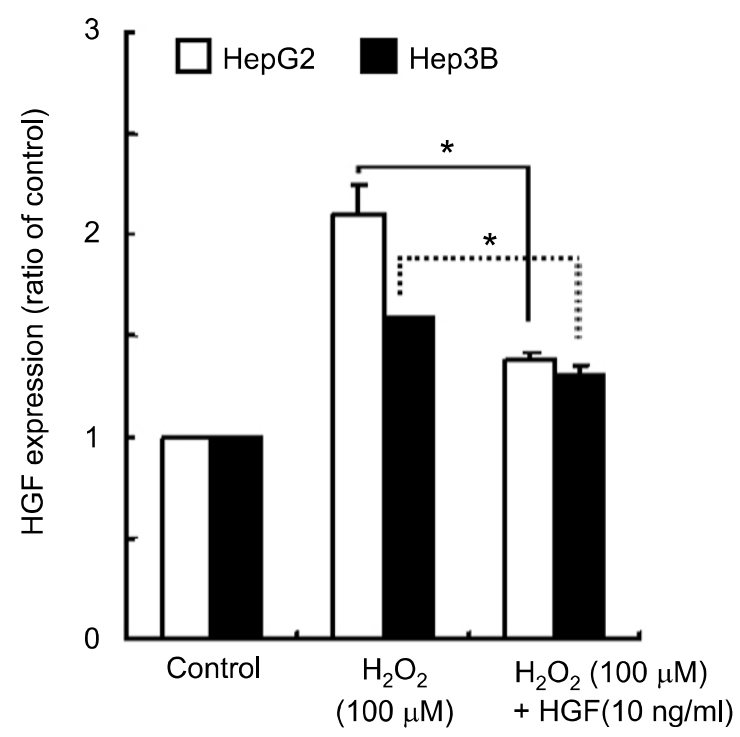

Figure 6. Expression level of HGF after treatment with $\mathrm{H}_{2} \mathrm{O}_{2}$ and/or $\mathrm{HGF}$. Cells were serum-starved and treated with $\mathrm{H}_{2} \mathrm{O}_{2}(100 \mu \mathrm{M})$ and/or HGF $(10 \mathrm{ng} / \mathrm{ml})$. The level of HGF mRNA was measured by real-time RT-PCR analysis. Values are means $\pm S D$ of triplicates of three independent experiments. Statistical significance was estimated by Student's $t$-test $\left({ }^{*} P\right.$ $<0.05)$. levels of HGF mRNA were suppressed by exogenous treatment of $\mathrm{HGF}$ and $\mathrm{H}_{2} \mathrm{O}_{2}$ (Figure 6).

\section{Effect of $\mathrm{H}_{2} \mathrm{O}_{2}$ on uPA production}

UPA gradually accumulated in both cell lines after treatment with HGF. Treatment with $\mathrm{H}_{2} \mathrm{O}_{2}$ resulted in an increase in the uPA protein level in both cell lines. When we treated cells with $\mathrm{H}_{2} \mathrm{O}_{2}$ and $\mathrm{HGF}$, the UPA protein level was decreased (Figure 7).

\section{Effect of $\mathrm{H}_{2} \mathrm{O}_{2}$ on ERK and p38 activation induced by HGF}

To demonstrate the effect of $\mathrm{H}_{2} \mathrm{O}_{2}$ on HGF-mediated ERK and p38 activation, we treated both cells with $\mathrm{H}_{2} \mathrm{O}_{2}$. Treatment with $\mathrm{H}_{2} \mathrm{O}_{2}$ increased the activity of ERK and p38. When cells were treated with $\mathrm{H}_{2} \mathrm{O}_{2}$ and $\mathrm{HGF}$ together, the activation of ERK and p38 kinase was decreased (Figure 8).

\section{Effect of ERK and p38 inhibitor on $\mathrm{H}_{2} \mathrm{O}_{2}$-induced uPA expression}

To test whether ERK and p38 activation was involved in $\mathrm{H}_{2} \mathrm{O}_{2}$-mediated uPA secretion, cells were pretreated with PD 98059 or SB 203580, and UPA secretion was measured by Western blotting. Both cells showed that $\mathrm{H}_{2} \mathrm{O}_{2}$-mediated uPA secretion was reduced with increasing concentrations of PD 98059. Densitometric analysis indicated that $10 \mu \mathrm{M}$ PD 98059 reduced the urokinase secretion by 40-50\%. In contrast, pretreatment with SB 203580 increased UPA secretion. These results suggested that $\mathrm{H}_{2} \mathrm{O}_{2}$-mediated uPA secretion and the augmentation of this activity were regulated by ERK and p38 activation (Figure 9).

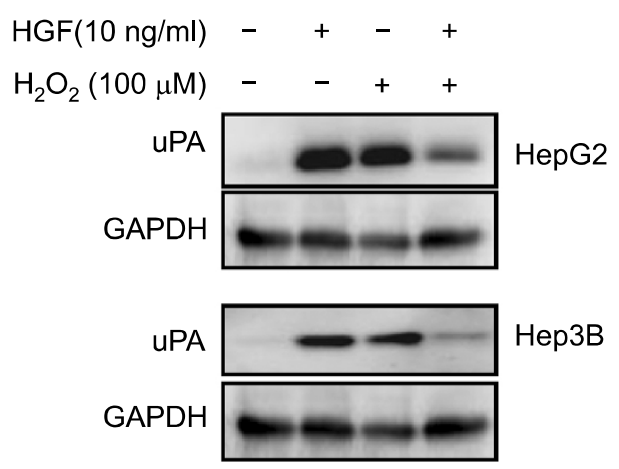

Figure 7. Effect of $\mathrm{H}_{2} \mathrm{O}_{2}$ on HGF-mediated up-regulation of UPA. Serum-starved cells were pretreated with or without $\mathrm{H}_{2} \mathrm{O}_{2}(100 \mu \mathrm{M})$ for $30 \mathrm{~min}$, and then treated with or without HGF $(10 \mathrm{ng} / \mathrm{ml})$. After incubation for $24 \mathrm{~h}$, uPA secreted in culture media was measured by Western blot analysis with a UPA antibody. Representative data from 3 independent experiments were shown. 


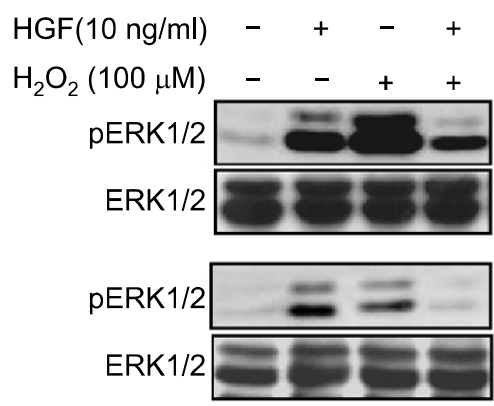

\section{Effects of PD 98059 and/or SB 203580 on $\mathrm{H}_{2} \mathrm{O}_{2}$-induced ERK1/2 phosphorylation}

To investigate the possibility of an interaction between ERK and p38 activation in $\mathrm{H}_{2} \mathrm{O}_{2}$-mediated uPA expression, the effect of SB 203580 on ERK activation was measured. Pretreatment with SB 203580 increased ERK phosphorylation in the $\mathrm{H}_{2} \mathrm{O}_{2}$-treated cells. Co-treatment with PD 98059 and SB 203580 decreased ERK phosphorylation. These results suggested that $\mathrm{H}_{2} \mathrm{O}_{2}$-mediated uPA secretion and the augmentation of this activity were regulated by ERK activation, and $\mathrm{p} 38$ activation might indirectly affect $\mathrm{H}_{2} \mathrm{O}_{2}$-mediated uPA secretion. In other words, the increments of $\mathrm{H}_{2} \mathrm{O}_{2}-$ mediated uPA secretion and its level of expression according to the treatment by SB 203580 were mediated through ERK activation (Figure 10).

\section{Discussion}

Metastasis is one of the most complicated and major pathologic processes underlying the poor prognosis for cancer patients. Studies of the mole-

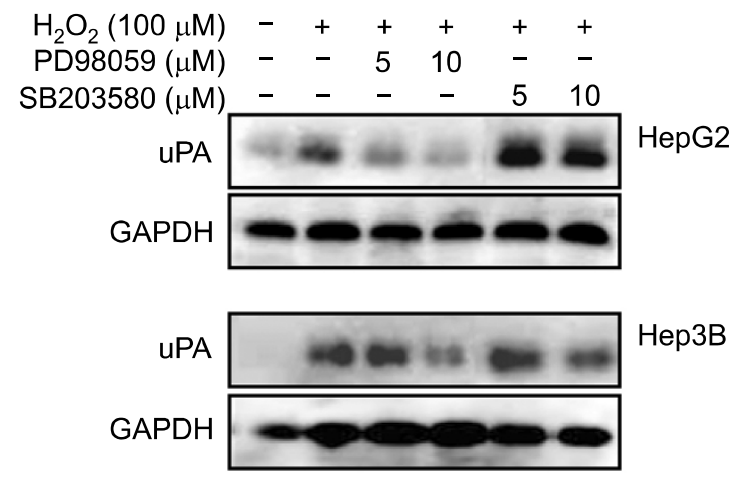

Figure 9. Effect of PD 98059 or SB 203580 on HGF-mediated up-regulation of uPA. Serum-starved cells were pretreated with or without $\mathrm{H}_{2} \mathrm{O}_{2}$ $(100 \mu \mathrm{M})$ for $30 \mathrm{~min}$ and then treated with PD $98059(5$ and $10 \mu \mathrm{M})$ or SB 203580 ( 1 and $5 \mu \mathrm{M}$ ). After incubation for $24 \mathrm{~h}$, uPA in culture media was measured by Western blot analysis. Representative data from 3 independent experiments were shown. cular mechanisms for these processes are important for developing more effective anti-metastatic strategies. Liotta et al. (1988) reported that tumor cell invasion comprises three steps: 1 ) adhesion of tumor cells to the normal cell layer; 2) motility of tumor cells, and 3) degradation of extracellular matrices. Inhibition of any of these steps may effectively suppress invasion and inhibit metastasis.

Tumor cells are known to produce a larger amount of ROS than normal cells because of their rapid and endless proliferation (Szatrowski and Nathan, 1991). Kozuki et al. $(2000,2001)$ showed that ROS potentiate the invasive activity of the rat ascites hepatoma cell line, AH 109A, in a co-culture system with rat mesentery-derived mesothelial cells, and some food factors possessing antioxidative properties were shown to inhibit the invasion of AH 109A cells.

HGF is now known to be a broad-spectrum mitogen of a variety of cell types, including melanocytes, endothelial cells, and epithelial cells. Thus, HGF is a multifunctional cytokine that mediates epithelial-mesenchymal interactions. It is well-esta-

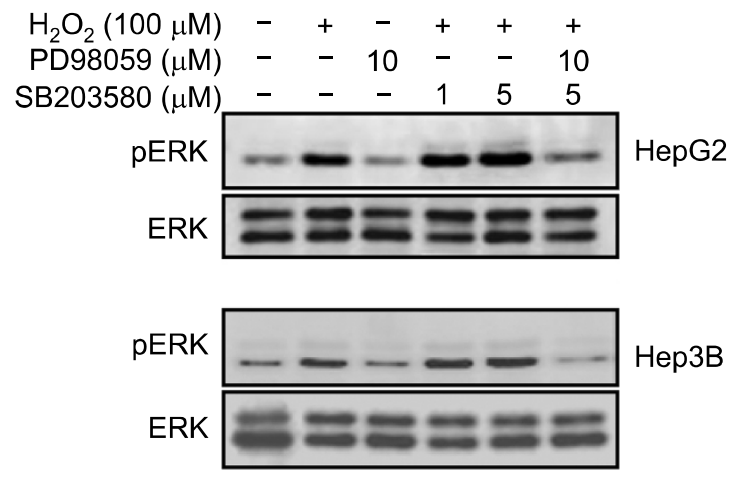

Figure 10. Effects of PD 98059 and/or SB 203580 on $\mathrm{H}_{2} \mathrm{O}_{2}$-induced ERK phosphorylation. Serum-starved cells were pretreated with PD 98059 (10 $\mu \mathrm{M})$ and/or SB $203580(1$ and $5 \mu \mathrm{M})$ for $30 \mathrm{~min}$ and then treated with HGF $(10 \mathrm{ng} / \mathrm{ml})$ for $15 \mathrm{~min}$. ERK activation was evaluated by Western blot analysis. Representative data from 3 independent experiments were shown. 
blished that membrane-localized NADPH oxidase is responsible for the generation of intracellular ROS triggered by receptor binding of numerous peptide growth factors, such as PDGF, HGF, insulin, VEGF, and TNF- $\alpha$, triggering cell proliferation, differentiation, and apoptosis (Choi et al., 2005). ROS can also be induced in the integrin-mediated pathway in a NADPH oxidase-dependent manner for the $\mathrm{G}_{1} / \mathrm{S}$ transition (Honore et al., 2003). It is worthy of noting that Rac GTPase, which is one of the important mediators of cell migration and invasion (Yamazaki et al., 2005), is the upstream signal enzyme for NADPH oxidase-dependent ROS generation (Bokoch and Knaus, 2005) Rac1regulated ROS production has been implicated in apoptosis. In contrast, pleiotropic protein kinase Akt protects against apoptosis. However, the proand anti-apoptotic mechanisms of Rac1 and Akt, respectively, and the intersection between these mechanisms are incompletely understood. In a model of oxidative stress and apoptosis induced by hypoxia/reoxy generation in primary hepatocytes, activation of the PI3-kinase-Akt axis by the prosurvival HGF inhibited Rac1 activation and intracellular ROS production and suppressed apoptosis (Ozaki et al., 2003). In our study, we showed HGF suppressed Rac-1 protein production, and suppression of PI3K with specific inhibitor induced intracellular ROS production.

Miura et al. (2003) reported that ROS promotes rat ascites hepatoma cell invasion. To investigate these mechanisms, they examined the involvement of motility factors, particularly HGF. Treatment with ROS augmented amounts of HGF mRNA and HGF concentration in the medium and showed an increased invasive activity, which was blocked by simultaneous pretreatment with anti-HGF antibody. These results suggest that the invasive activity is mediated by the autocrine and paracrine pathways of HGF, and ROS potentiates invasive activity by inducing gene expression of HGF. In our study, $\mathrm{H}_{2} \mathrm{O}_{2}(100 \mu \mathrm{M})$ increased HGF gene expression. But, when co-cultured with $\mathrm{HGF}$ and $\mathrm{H}_{2} \mathrm{O}_{2}$, it showed down-regulation of HGF gene expression.

UPA is one of the acute phase reactants and its synthesis is regulated by pro-inflammatory cytokines. UPA catalyses the conversion of zymogen plasminogen to the broad-spectrum serine protease plasmin. In addition to its role in fibrolysis, plasmin not only cleaves extracellular matrix substrate, but activates pro-matrix metalloproteinase zymogen, and therefore, plays a central role in many aspects of cellular regulation, such as tissue remodeling, inflammation, cell migration, and tumor metastasis (Blasi, 1996; Schmitt et al., 1997). RC-K8 human lymphoma cells synthesize and secrete
uPA in conditioned medium and produce massive metastatic tumors in the lungs and liver when injected intraperitoneal into immunosuppressed newborn hamsters (Kubonishi et al., 1986). Miyazono et al. (2004) reported $\mathrm{H}_{2} \mathrm{O}_{2}$-induced uPA expression in RC-K8 cells. These data are similar to our results.

Oxidative stress constitutes a major threat to organisms living in an aerobic environment and for humans. It might have a causative role in many disease processes. Oxidants can trigger the activation of multiple signaling pathways that influence the cytotoxicity observed in affected cells, including the phosphorylation cascades leading to the activation of MAPK (Waskiewicz and Copper, 1995; Robinson and Cobb, 1997). Wang et al. (1998) showed that treatment of HeLa cells and human cervical carcinoma with $\mathrm{H}_{2} \mathrm{O}_{2}$ resulted in a timeand dose-dependent induction of apoptosis accompanied by sustained activation of all three MAPK subfamilies. This $\mathrm{H}_{2} \mathrm{O}_{2}$-induced apoptosis was markedly blocked when ERK2 activation was selectively inhibited by PD 98059 .

How ROS exerts its cellular effect might better be investigated by identifying its intracellular targets. ROS can act as a second messenger for regulation of diverse cellular processes by oxidation of cysteine on the critical target molecules, including kinases, phosphatase (Savaraj et al., 2005), redoxsensitive transcription factors (Storz and Polla, 1996), cell cycle regulators (Rudolph, 2005), and cell membrane lipids (Poli et al., 2004), of which protein kinase and protein tyrosine phosphatase are the most relevant to tumor cell invasion. How MAPK is activated by ROS to trigger cell migration is not clear. Protein kinase may be activated by ROS for a variety of cellular effects. Moreover, protein kinase is also an upstream kinase of MAPK required for cell migration (Kruger and Reddy, 2003; Kenmorgant et al., 2004). Wu et al. (2006) found ROS plays a central role for sustained ERK activation leading to cell migration of the hepatoma cell line, HepG2.

In our study, the effects of PD 98059, an ERK kinase (MEK) inhibitor, and SB 203580, a p38 MAPK inhibitor, were measured in order to clarify which signaling pathway might play the more import role in $\mathrm{H}_{2} \mathrm{O}_{2}$-induced uPA secretion in the hepatoma cell lines. While treatment with $P D$ 098059 decreased the $\mathrm{H}_{2} \mathrm{O}_{2}$-induced uPA secretion, pre-treatment with SB 203580 increased UPA secretion. Increments of $\mathrm{H}_{2} \mathrm{O}_{2}$-mediated uPA expression after treatment of SB 203580 pre-treatment were also shown to be mediated by ERK activation. When we pretreated with PD 98059 and SB 203580, ERK activity was decreased. Julio et al. 
(2003) also show that in breast, prostate, melanoma, and fibrosarcoma cell lines, the level of active phospho-ERK and the ERK/p38 activity ratio predicted the in vivo behavior in $\sim 90 \%$ of the cell lines tested. Modulation of the ERK/p38 activity ratio by multiple pharmacologic and genetic interventions confirms that high ERK/p38 ratio favors tumor growth, whereas high p38/ERK ratio induces tumor growth arrest in vivo and that ERK is negatively regulated by p38 (Aguirre-Ghiso et al., 2003).

In the present study, we found that HGF decreased intracellular ROS level and increased the UPA protein levels. Treatment with $\mathrm{H}_{2} \mathrm{O}_{2}$ also increased HGF mRNA and protein levels and the uPA protein levels. However, cotreatment with $\mathrm{HGF}$ and $\mathrm{H}_{2} \mathrm{O}_{2}$ decreased the ROS levels, the HGF mRNA and protein levels increased by $\mathrm{H}_{2} \mathrm{O}_{2}$ treatment and the UPA protein levels increased by $\mathrm{H}_{2} \mathrm{O}_{2}$ or $\mathrm{HGF}$. These results suggest that exogenous HGF might play a negative role in the regulation of UPA protein levels increased by $\mathrm{H}_{2} \mathrm{O}_{2}$ treatment (Figure 11). However, further study would be necessary to elucidate by which mechanism exogenous HGF regulates UPA protein levels through the regulation of intracellular ROS levels and signal pathways.

In summary, our findings implicate a novel relationship between ROS and UPA production in the control of tumor invasion and metastasis. The balance of this relationship, controlled by cytokines, such as HGF, and the timing between such stimuli, has a profound impact on the tumor progression. The major intracellular ROS were known to be derived from mitochondrial origin. It is worthy of noting that generation of ROS through mitochondria was associated with integrin-mediated

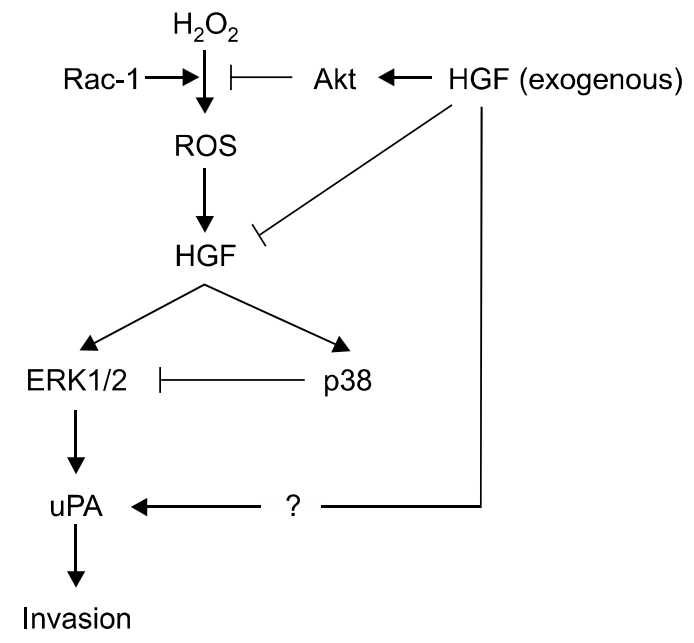

Figure 11. Interaction of exogenous $\mathrm{HGF}$ with $\mathrm{H}_{2} \mathrm{O}_{2}$ in UPA expression. cell shape change and gene expression of MMP. Future studies will be directed towards whether NADPH oxidase and/or mitochondria-dependent ROS generation are directly associated with tumor cell invasion.

\section{Methods}

\section{Cell cultures}

Human hepatoma cell lines, HepG2 and Hep3B were obtained from the Korea Cell Line Bank (Seoul, Korea). Cells were maintained in DMEM supplemented with $10 \%$ FBS, $1 \mathrm{mM}$ sodium pyruvate, $0.1 \mathrm{mM}$ non-essential amino acids, $2 \mathrm{mM}$ L-glutamine, a 2-fold vitamin solution, and 50 $\mathrm{U} / \mathrm{ml}$ penicillin/streptomycin (Life Technologies, Inc., Gaithersburg, MDA) in an incubator under a humidified atmosphere of $5 \% \mathrm{CO}_{2}$ and $95 \%$ air at $37^{\circ} \mathrm{C}$. Unless otherwise noted, cells were passaged and removed at $70-80 \%$ confluency.

\section{Reagents and antibodies}

Antibodies against ERK, p38, phospho-ERK, and phosphop38 were purchased from Cell Signaling Technology (Beverly, MA). Antibodies against AKT, phosphor-AKT, and Rac1 were from Santa Cruz Biotechnology, Inc. (Santa Cruz, CA). hydrogen peroxide $\left(\mathrm{H}_{2} \mathrm{O}_{2}\right)$, and $\mathrm{LY} 294002$ were purchased from Sigma (St. Louis, MO). 2'-7'-dichlorofluorescin diacetate (DCF-DA) was obtained from Molecular Probes (Eugene, OR). HRP-conjugated anti-mouse and anti-rabbit antibodies were purchased from Bio-Rad Laboratories (Philadelphia, PA). Recombinant human HGF (R\&D systems, Inc, Minneapolis, MN) and human UPA antibody (389, American Diagnostica, Greenwich, CT) were also purchased.

\section{Real-time PCR}

Complementary DNA (cDNA) was synthesized from total RNA using MMLV reverse transcriptase (Promega Corp., Madison, $\mathrm{WI}$ ) by the oligo(dT) priming method in a $10 \mu \mathrm{l}$ reaction mixture. Real-time PCR analysis was performed using a lightCycler1.5 Instrument (Roche, Mannheim, Germany). PCR was performed in a LightCycler capillary in a $10 \mu \mathrm{l}$ reaction volume that contained $1^{*}$ DNA Master SYBR Green I, $2.5 \mathrm{mM} \mathrm{MgCl}_{2}, 1 \mu \mathrm{l} \mathrm{cDNA}$, and $0.4 \mu \mathrm{M}$ primers. The PCR protocol was as follows: initial denaturation for $2 \mathrm{~min}$ at $95^{\circ} \mathrm{C}, 45$ cycles at $95^{\circ} \mathrm{C}$ for $10 \mathrm{~s}, 60^{\circ} \mathrm{C}$ for $5 \mathrm{~s}$, and $72^{\circ} \mathrm{C}$ for $12 \mathrm{~s}$. Results were analyzed with LightCycler Software, version 3.5.3.

\section{Western blot analysis}

Cells were harvested and incubated with a lysis buffer (50 $\mathrm{mM}$ Tris- $\mathrm{HCl}$ [pH 8.0], $150 \mathrm{mM} \mathrm{NaCl}, 1 \mathrm{mM}$ EDTA, $1 \%$ Trion X-100, $10 \%$ glycerol, $1 \mathrm{mM}$ PMSF, $1 \mathrm{mM}$ sodium vanadate, and $5 \mathrm{mM} \mathrm{NaF}$ ) with protease inhibitors and centrifuged at $15,000 \mathrm{rpm}$ at $4^{\circ} \mathrm{C}$ for $10 \mathrm{~min}$. Proteins (50 $\mu \mathrm{g}$ ) were separated on $10 \%$ SDS-polyacrylamide gels and 
transferred to nitrocellulose membranes. The membranes were soaked with $5 \%$ non-fat dried milk in $10 \mathrm{mM}$ Tris- $\mathrm{HCl}$ (pH 7.5), $150 \mathrm{mM} \mathrm{NaCl}$, and 0.05\% Tween-20 (TTBS) for $30 \mathrm{~min}$ and then incubated overnight with a primary antibody at $4^{\circ} \mathrm{C}$. After washing 6 times with TTBS for $5 \mathrm{~min}$, the membranes were incubated with a HRP-conjugated secondary antibody for $90 \mathrm{~min}$ at $4^{\circ} \mathrm{C}$. The membranes were rinsed 3 times with TTBS for $30 \mathrm{~min}$ and the antigen-antibody complex was detected using the enhanced chemiluminescence detection system.

\section{Measurement of Rac1 activity}

Rac1 activity was measured using the Rac1 activation kit (Upstate Biotechnology, NY). Briefly, whole-protein extracts were immunoprecipitated with the protein binding domain of PAK-1 PBD. PAK-1 PBD only binds to activated forms of Rac1 and cdc42. Immunoprecipitated proteins were separated in SDS-polyacrylamide gels and blotted with antiRacl.

\section{Measurement of ROS}

ROS production was measured using the DCF-DA assay. In brief, HepG2 and Hep3B cells were seeded in $60 \mathrm{~mm}$ culture dishes at $70 \%$ confluence and then starved in DMEM for $24 \mathrm{~h}$. The cells were treated with $\operatorname{HGF}(0,10$, or $40 \mathrm{ng} / \mathrm{ml}$ ). After treatment with HGF, cell were incubated with $10 \mu \mathrm{M}$ of DCF-DA for $10 \mathrm{~min}$. The cells were harvested, washed once, and resuspended in PBS. Fluorescence was monitored using a flow cytometer (BectonDickinson, San Jose, CA). The mean of the DCF fluorescence intensity was obtained from 10000 cells using 480 $\mathrm{nm}$ excitation and $540 \mathrm{~nm}$ emission settings. By using the same settings, the fluorescent intensity was obtained from each experimental group. Fluorescent levels were expressed as the percentage increase over the control.

\section{Statistical analysis}

Results of three independent experiments were expressed as the means \pm SD and were analyzed by Student's $t$-test.

\section{Acknowledgements}

This work was supported by the Korea Science and Engineering Foundation (KOSEF) NCRC grant funded by the Korea government (MEST) (No. R15-2004-033-05001-0).

\section{References}

Aguirre-Ghiso JA, Estrada Y, Liu D, Ossowski L. ERKMAPKActivity as a Determinant of Tumor Growth and Dormancy; Regulation by p38SAPK1. Cancer Research 2003; 63:1684-95

Andreasen PA, Kjoller L, Christensen L, Nielsen LS, Duffy MJ. The urokinase-type plasminogen activator system in cancer metastasis: a review. Int J Cancer 1997;72:1-22

Aslan M, Ozben T. Oxidants in receptor tyrosine kinase signal transduction pathways. Antioxidants \& Redox Signalling 2003;5:781-8

Berra E, Diaz-Meco MT, Lozano J, Frutos S, Municio MM, Sanchez $\mathrm{P}$, et al. Evidence for a role of MEK and MAPK during signal transduction by rotein kinase $\mathrm{C}$ zeta. EMBO Journal 1995;14: 6157-63

Blasi F. The urokinase receptor and cell migration. Semin Thromb Hemost 1996;22:513-6

Bokoch GM, Knaus UG. NADPH oxidases: Not just for leukocytes anymore! Trends in Biochemical Sciences 2005; 28:502-8

Chiarugi P. PTPs versus PTKs: The redox side of the coin. Free Radical Research 2005;39:353-64

Choi MH, Lee IK, Kim GW, Kim BU, Han YH, Yu DY, et al. Regulation of PDGF signalling and vascular remodelling by peroxiredoxin II. Nature 2005;435:347-53

Gupta A, Rosenberger SF, Bowden G.T. Increased ROS levels contribute to elevated transcription factor and MAP kinase activities in malignantly progessed mouse keratinocyte cell lines. Carcinogenesis 1999;20:2063-73

Honore S, Kovacic H, Pichard V, Briand C, Rognoni JB. Alpha2betal-integrin signaling by itself controls $\mathrm{GI} / \mathrm{S}$ transition in a human adenocarcinoma cell line (Caco-2): Implication of NADPH oxidase-dependent production of ROS. Experimental Cell Research 2003;285:59-71

Julio A, Guirre G, Yeriel E, David L, Liliana O. ERK MAPK activity as a determinant of tumor growth and dormancy; regulation by p38SAPk1. Cancer Research 2003;63:168495

Kenmorgant S, Zicha D, Parker PJ. PKC controls HGFdependent c-Met traffic, signalling and cell migration. EMBO Journal 2004;23:3721-34

Kozuki Y, Miura Y, Yagasaki K. Inhibitory effects of carotenoids on the invasion of rat ascites hepatoma cells in culture. Cancer Lett 2000;151:111-5

Kozuki Y, Miura Y, Yagasaki K. Inhibitory effect of curcumin on the invasion of rat ascites hepatoma cells in vitro and $e x$ vivo. Cytotechnology 2001;35:57-63

Kruger JS, Reddy KB. Distinct mechanisms mediate the initial and sustained phases of cell migration in epidermal growth factor receptor-overexpressing cells. Molecular Cancer Research 2003;1:801-9

Kubonishi I, Niiya K, Yamashita M, Yano S, Abe T, Ohtsuki $Y$, et al. Characterization of a new human lymphoma cell line (RC-K8) with $\mathrm{t}(11 ; 14)$ chromosome abnormality. Cancer 1986;58:1453-60

Lee $\mathrm{KH}$, Hyun MS, Kim JR. Invasion-metastasis by hepatocyte growth factor/c-Met signaling concomitant with induction of urokinase plasminogen activator in human pancreatic cancer: Role as therapeutic target. Cancer Research and Treatment 2003;35:207-12

Liotta LA, Wewer U, Rao NC, Schiffmann E, Stracke M, Guirguis R, Thorgeirsson U, Muschel RM, Sobel M. Biochemical mechanism of tumor invasion and metastasis. Prog Clin Biol Res 1988;2563-16 
Maulik A, Shrikhande T. Kijima PC, Ma PT, Morrison RS Roleof the hepatocyte growth factor receptor, c-Met. in oncogenesis and potential for therapeutic inhibition. Cytokine Growth Factor Rev 2002;13:41-59

Miura Y, Kozuki Y, Yagasaki K. Potentiation of invasive activity of hepatoma cells by reactive oxygen species is mediated by autocrine/paracrine loop of hepatocyte growth factor. Biochem Biophys Res Commun 2003;305:160-5

Miyazono T, Niiya K, Kiguchi T, Sakuragawa N, Harada M, Watanabe A. Oxidative stress induces urokinase-type plasminogen activator in RC-K8 human malignant lymphoma cells and H69 human small cell lung carcinoma cells. Fibrinolysis Proteolysis 2004;14:366-73

Ozaki M, Haga S, Zhang HQ, Irani K, Suzuki S. Inhibition of hypoxia/reoxygenation-induced oxidative stress in HGFstimulated antiapoptotic signaling: role of PI3-K and Akt kinase upon rac1. Cell Death and Differention 2003;10: 508-15

Parr C, Jiang WG. Expression of hepatocyte growth factor/ scatter factor, its activator, inhibitors and the c-Met receptor in human canccr cells. Int J Oncol 2001;19:857-63

Poli G, Leonarduzzi G, Biasi F, Chiarpotto E. Oxidative stress and cell signalling. Current Medicinal Chemistry 2004; 11:1163-82

Radisky DC, Levy DD, Littlepage LE, Liu H, Nelson CM, Fata $\mathrm{JE}$, et al. Rac-lb and reactive oxygen species mediate MMP-3-induced EMT and genomic instability. Nature 2005; 436:123-7

Robinson MJ, Cobb MH. Mitogen-activated protein kinase pathways. Curr Opin Cell Biol 1997;9:180-6

Rudolph J. Redox regulation of the Cdc25 phosphatases. Antioxidants and Redox Signalling 2005;7:761-7

Savaraj N, Wei Y, Unate H, Liu PM, Wu CJ, Wangpaichitr M, et al. Redox regulation of matrix metalloproteinase gene family in small cell lung cancer cells. Free Radical Research
2005;39:373-81

Schmitt M, Harbeck N, Thomssen C, Wilhelm O, Magdolen $\mathrm{V}$, Reuning $\mathrm{U}$, et al. Clinical impact of the plasminogen activation system in tumor invasion and metastasis: prognostic relevance and target for therapy. Thromb Haemost 1997;78:285-96

Schonwasser DC, Marais RM, Marshall CJ, Parker PJ. Activation of the mitogen-activated protein kinase/ extracellular signal-regulated kinase pathway by conventional, novel, and atypical protein kinase $C$ isotypes. Molecular and Cellular Biology 1998;18:790-8

Storz G, Polla BS. Transcriptional regulators of oxidative stress-inducible genes in prokaryotes and eukaryotes. EXS 1996; $77: 239-54$

Storz P. Reactive oxygen species in tumor progression. Frontiers in Bioscience 2005;10:1881-96

Szatrowski TP, Nathan CF. Production of large amount of hydrogen peroxide by humantumor cells. Cancer Res 1991; 51:794-8

Wang X, Martindale JL, Liu Y, Holbrook NJ. The Cellular response to oxidative stress: influences of mitogen-activated protein kinase signalling pathways on cell survival. Biochem J 1998;333:291-300

Waskiewicz AJ, Cooper JA. Mitogen and stress response pathways: MAP kinase cascades and phosphatase regulation in mammals and yeast. Curr Opin Cell Biol 1995;7: 798-805

Wu WS, Tsai RK, Chang CH, Wang S, Wu JR, Chang YX. Reactive oxygen species mediated sustained activation of protein kinase $C$ and ERK for migration of human hepatoma cell HepG2. Molecular Cancer Research 2006;4:747-58

Yamazaki D, Kurisu S, Takenawa T. Regulation of cancer cell motility through actin reorganization. Cancer Science 2005; 9:379-86 